Article

\title{
The Economic Effects of the Development of the Renewable Energy Industry in China
}

\author{
Jia Liu, Jizu Li and Xilong Yao * \\ School of Economics and Management, Taiyuan University of Technology, Taiyuan 030024, China; \\ liujialiaocheng@163.com (J.L.); lijizu@tyut.edu.cn (J.L.) \\ * Correspondence: xilongyao@163.com; Tel.: +86-152-3410-6703
}

Received: 23 April 2019; Accepted: 9 May 2019; Published: 12 May 2019

\begin{abstract}
It is believed that renewable energy may become a dominant energy in the future. However, whether renewable energy can promote industry development like the use of fossil energy is still unknown. This paper uses social accounting matrix (SAM) multiplier model to analyze the economic effects of renewable and coal energy in China. The transmission mechanisms of renewable and coal energy on production factors are also compared from the perspective of sector industry chain based on the structural path analysis (SPA) analysis method. We found that; renewable energy plays a stronger role in promoting the national economy than coal energy. Meanwhile, renewable energy can better promote the upgrading of the industrial structure compared with coal energy. Additionally, renewable energy affects economic development, mainly through the intermediate industries such as electrical machinery manufacturing and transportation, warehousing and service industries. These findings provide further insights into the influence path of renewable energy, which yields important implications for reasonably designing and choosing new energy development planning.
\end{abstract}

Keywords: renewable energy; coal; SAM multiplier model; SPA analysis method

\section{Introduction}

As a leading energy in the future, renewable energy is conducive to reducing greenhouse gas and air pollutant emissions, and is favored by many countries [1]. For instance, China's total installed capacity of wind and photovoltaic power has reached the first place in the world in 2018, according to World Energy Outlook 2018 from International Energy Agency. However, the rapid development of renewable energy could inevitably lead to a series of problems. The most important one is whether the increased consumption of renewable energy can greatly affect the fossil energy-based economic development? Moreover, can the increased consumption of renewable energy better promote the upgrading of the industrial structure compared to increasing fossil energy consumption? Therefore, we aim to identify the impacts of renewable energy on the economy, and compare the results with coal resources, so as to find the role of renewable energy in promoting economic development. In addition, the influence path of renewable energy on economic development is also studied.

Existing studies have carried out some investigation on the relationship between renewable energy and economic development [2-4]. Some studies analyzed the impacts of renewable energy on employment, and sector output by Employment Rate Analysis and Supply Chain Analysis [5-7]. Yet, these two methods are considered more suitable for the evaluation of economic performance in small regions [8]. Others analyzed the causal relationship between the increased consumption of renewable energy and economic growth using econometric models [9-12]. However, it is argued that econometrics is a study of partial equilibrium without considering cross-sector linkages in the economy. Thus, I-O model and CGE model have been employed to study the relationship between renewable energy and economic growth [13-15]. This study aims to provide further evidence on the 
influence path of renewable energy on economic development using SAM model from the perspective of sector industry chain. In particular, the coal sector is incorporated to make an in-depth analysis of the impacts of renewable energy on economic growth by comparing the influence mechanisms of renewable and fossil energy. This is because coal resources account for more than $60 \%$ of China's total energy consumption in the past 10 years. Coal sector plays an important role in China's economy [16]. The characteristics of the national energy structure can affect renewable energy deployment and the relationship between renewable energy and economic growth [17]. In China, the importance of the coal industry, the maturity of the coal industry chain and the impact of coal industry on capital and labor will affect the technological progress and industrial development of renewable energy, thus affecting the relationship between renewable energy and economic growth.

This study contributes to the existing literature in three aspects.

First, a measurement and decomposition system of the effects of renewable energy from a multi-dimensional perspective is established. We use the SAM model to measure the total effects of renewable energy on economic growth. Then, the effects of renewable energy are decomposed from three perspectives: industrial linkages, factor returns and inter-sector cyclic feedback of endogenous accounts. This allows for an in-depth analysis of the effects of renewable energy on the composition of total economic output rather than on total economic output as a whole, which can overcome the deficiencies of traditional methods.

Second, the influence mechanism of renewable energy on economic growth is analyzed from the perspective of the sector industry chain. Previous studies mainly focus on the single causal relationship between renewable energy and economic growth, while little attention has been paid to the sector transmission mechanism [18-21]. In this paper, the direct and indirect influence paths of renewable energy on labor and capital elements are measured based on the SPA method under the SAM framework, and the key transmission path is identified. This may help further decompose the effect of renewable energy.

Third, the influence mechanisms of renewable energy and coal energy consumption on economic growth are compared. Renewable energy plays an important role in promoting the upstream industry, such as the manufacturing sector and producer service sector compared to coal energy. Existing literature mainly compares the economic benefits of different renewable energy technologies [1,22,23], while comparative analysis aiming at different economic benefits between renewable and fossil energy are rare. This paper compares renewable and coal energy considering sector relevance, which can fill this gap.

The rest of the study is structured as follows: Section 2 presents literature review. Section 3 describes the used method and data. In Section 4, we report and discuss the estimation results. Section 5 draws main conclusions and provides some policy implications.

\section{Literature Review}

There are four hypotheses about the relationship between renewable energy and economic growth: growth hypothesis, feedback hypothesis, conservative hypothesis and neutral hypothesis. A large number of studies claim that the development of renewable energy is conducive to economic growth [24,25], which supports the growth hypothesis. This is because renewable energy development can promote equipment upgrading and create more profits for enterprises [26], leading to the growth of per capita GDP [2]. Feedback hypothesis that emphasizes the interdependence between energy consumption and economic growth is supported by the two-way causality between energy consumption and economic growth. Similarly, changes in economic growth can also be reflected in energy consumption [4,27-31]. However, conservative hypothesis argues that the development of renewable energy has a negative impact on economic growth [32]. The high cost of renewable energy leads to a reduction in government and private budgets, accompanied by a reduction in investment and consumption, which is detrimental to employment and economic growth [9]. For example, Böhringer claim that the development of renewable energy has a negative impact on employment 
and welfare in Germany [33]. In addition, others find there is no significant relationship between renewable energy development and economic growth [34], which is in line with the neutral hypothesis. Obviously, completely different conclusions exist with regard to the effects of renewable energy on economic growth. This is likely due to the following reasons. First, the effects of renewable energy on economic growth depend on a country's economic development level [35]. Al-mulali find that the high income level is closely related to the sustained and significant positive impact of renewable energy consumption on economic growth [10]. Since different resource endowments, political and institutional arrangements, energy policies and cultures can affect the relationship between renewable energy and economy [36]. Second, the above sample intervals are diverse, so that research objects are in different economic development stages, thus resulting in different results. Third, different model specification and indicators have great influence on regression results, leading to the uncertainty of the results (differences in coefficients and significance levels).

The impacts of renewable energy on the economy include direct and indirect ones. A large body of literature focuses on the direct impact of renewable energy $[2,11,19,37,38]$. Some also assess the direct and indirect impacts of renewable energy from the life cycle perspective [20,39]. For example, Lantz assessed the direct, indirect and induced effects of wind power industry on the economy, claiming that these three effects come from the expenditure of the wind power industry, the increased demand for basic goods and services, and the reinvestment of direct and indirect beneficiaries, respectively [40]. However, indirect impacts assessed from the life cycle perspective only consider sectors related to renewable energy. Renewable energy life cycle can be divided into five phases: research and design, development and manufacturing, construction and installation, operation and maintenance (O\&M) or services, renewal and/or demolition [5].

Many methods are adopted to study the economic benefits of renewable energy, such as employment rate analysis, supply chain analysis, econometric model, input-output analysis and CGE analysis [5-7,33,40,41]. It is argued that employment rate analysis and supply chain analysis are more suitable for assessing the economic benefit in small regions [8]. Econometrics is a study of partial equilibrium with little consideration of the economic impacts of cross-sectorial linkages in the economy. However, the development of the renewable energy sector not only directly increases its own demand, but also requires input from other sectors at different stages of the industrial process, thus generating direct and indirect needs [42]. Therefore, some studies use input-output models to calculate the economic impacts of renewable energy. For example, Fanning used the input-output model to study the direct and indirect effects of wave and tidal energy on the economy [43]. Slattery et al., assessed the direct, indirect and induced effects of wind energy development on the economy in western Texas [20]. Madlener and Koller studied the effects of bioenergy development on domestic value added, employment and finance in Austrian federal province of Vorarlberg [21]. Input-output analysis can reflect the change of the final demand for renewable energy and influence the economy through inter-industry linkages in the production system, while the interaction of production system and other social institutions are not included. SAM-based Multiplier Analysis takes into account the interaction of production systems, households and social institutions in the economy, which can further analyze labor force, human capital and social welfare $[44,45]$. Compared with IO or extended IO methods, SAM can capture richer interdependent endogenous dynamics in the economy, as well as the diversity of income sources and consumption structures in households and business groups, which can obtain more accurate results [44]. Moreover, an important feature of SAM method lies in its ease of decomposition, which can help understand the linkages in the economy and the impacts of exogenous shocks. Additionally, some papers take renewable and non-renewable energy as production factors into CGE model to assess the impacts of renewable energy on economic growth. Although CGE method can respond to market price changes through substitution effect by considering the market mechanism and the behavior of market participants, the renewable energy is likely to have a non-linear impact on the economy in this model $[4,41,46,47]$. In addition, some studies compare the economic benefits of different types of renewable energy by classifying them $[1,20,21]$. A few comparative studies on the 
economic benefits between renewable and fossil energy are based on econometric methods [25,48,49]. They analyze the single causal relationship between renewable, non-renewable energy consumption and economic growth without considering different influence mechanisms between them. This study compares the role of coal and renewable energy in economic development to reveal the impacts of China's energy transformation and development on the economy.

\section{Methods}

As mentioned above, methods such as employment rate analysis, supply chain analysis, econometric model, input-output analysis and CGE can analyze the impacts of renewable energy on the economy. However, we employ the SPA method to conduct our analysis under the SAM framework for the following reasons. First, it can determine a complete path network, emphasizing the transmission path from the initially affected department to other accounts. Second, the importance of various paths and the key path can be identified through this method [44,50]. Therefore, we study the economic benefits of renewable energy based on the SPA method under the SAM framework: (1) we measure the overall impacts of renewable energy and coal on the economy using SAM multiplier model that can reflect the interaction of production system, households and social institutions in the economy; (2) we decompose the overall economic effects of renewable energy and coal from three dimensions-transfer effect, open-loop effect (spillover effect), and closed-loop effect (feedback effect); (3) we analyze the transmission mechanisms of renewable energy and coal on economic growth from the perspective of sector industrial chain based on SPA analysis.

Note that the transfer effect reflects the "endogenous account" effect, that is, the multiplier effect of exogenous injection of a set of accounts on the same set of accounts. This part is an input-output multiplier for activities, and it reflects the income transfer mode between families for households or businesses. The open-loop effect (spillover effect) reflects the effect of exogenous injection of one set of accounts (e.g., activities) on another set of accounts (e.g., families). The closed-loop effect (feedback effect) shows the multiplier effect due to the complete circulating flow [51,52].

\subsection{SAM Multiplier Model}

As a comprehensive macroeconomic data framework, SAM is a powerful tool for studying energy issues. The SAM model is a top-down economic technique, which was developed by Defournyand Thorbecke [50]. In addition to production activities, the main elements (labor, capital), institutions (households, companies) in the SAM framework are also included in the endogenous accounts compared to the I-O framework. Exogenous accounts include government consumption, investment and exports, which influence the economy through the interplay among production activities, factors and endogenous accounts of institutions. The structures of SAM table used in this study are displayed in Table 1.

Table 1. The structures of SAM.

\begin{tabular}{ccccccc}
\hline & & \multicolumn{3}{c}{ Endogenous Accounts } & Exogenous Accounts & Total \\
\cline { 2 - 5 } & $\begin{array}{c}\text { Production } \\
\text { Activities }\end{array}$ & Factors & Institutions & $\begin{array}{c}\text { Sum of other } \\
\text { Accounts }\end{array}$ & \\
\hline \multirow{2}{*}{$\begin{array}{c}\text { Endogenous } \\
\text { accounts }\end{array}$} & $\begin{array}{c}\text { activitios } \\
\text { Factors }\end{array}$ & $T_{11}$ & 0 & $T_{13}$ & $x_{1}$ & $y_{1}$ \\
& Institutions & $T_{21}$ & 0 & 0 & $x_{2}$ & $y_{2}$ \\
\hline \multicolumn{2}{c}{ Exogenous account } & 0 & $T_{32}$ & $T_{33}$ & $x_{3}$ & $y_{3}$ \\
\hline \multicolumn{2}{c}{ Total } & $L_{1}$ & $L_{2}$ & $L_{3}$ & $t$ & $y_{4}$ \\
\hline
\end{tabular}

Here, $T_{11}$ gives the intermediate input requirements; $T_{13}$ reflects the expenditure pattern of the various institutions; $T_{21}$ allocates the value added generated by the various production activities 
into income accruing to the factors of production; $T_{32}$ maps the factorial income distribution into the institutions income distribution; $T_{33}$ captures the income transfers within and among institutions [50].

Coefficient matrix of intermediate inputs $\left(A_{n}\right)$ is defined in SAM, which obtained from $T_{n}$. The value of each element in $A_{n}$ is obtained by dividing the value of each element in the endogenous account by the total value of the column in which it is located. $A_{11}$ is the direct consumption coefficient matrix in the IO table. The matrix $A_{n}$ can be expressed as:

$$
A_{n}=\left[\begin{array}{ccc}
A_{11} & 0 & A_{13} \\
A_{21} & 0 & 0 \\
0 & A_{32} & A_{33}
\end{array}\right]
$$

In the standard SAM model, the total revenue of an endogenous account can be expressed as:

$$
Y_{n}=A_{n} Y_{n}+X_{n}=\left(1-A_{n}\right)^{-1} X_{n}=M_{a} X_{n}
$$

where $Y_{n}$ is a $m \times 1$ vector of total outputs from $\mathrm{n}$ production activities; $n$ is the number of sectors in the SAM model; $X_{n}$ denotes the final demand of products, including government consumption demand, investment demand and export; $\left(1-A_{n}\right)^{-1}$ denotes Leontief inverse matrix; $I$ is a $n \times n$ unit matrix [44].

$M_{a}$ denotes account multiplier matrix, which is the core of SAM multiplier analysis and a starting knot of structured path analysis. As the information obtained from the account multiplier matrix is very limited, we decompose $M_{a}$ to analyze the impacts and paths of investment in renewable energy and coal energy sector on each endogenous account.

Here, a reversible diagonal matrix A with the same dimension as $A_{n}$ is introduced,

$$
A=\left[\begin{array}{ccc}
A_{11} & 0 & 0 \\
0 & 0 & 0 \\
0 & 0 & A_{33}
\end{array}\right]
$$

where $A_{11}$ and $A_{33}$ reflect the mutual expenditure and transfer within the production activity account and the institutional account respectively.

Equation (2) can be used to make the following mathematical transformation:

$$
\begin{aligned}
Y_{\mathrm{n}} & =A_{n} Y_{n}+X_{n}=\left(A_{n}-A\right) Y_{n}+A Y_{n}+X \\
& =(I-A)^{-1}\left(A_{n}-A\right) Y_{n}+(I-A)^{-1} X \\
& =\left(I-A^{* 3}\right)-1\left(I+A^{*}+A^{* 2}\right)(I-A)^{-1} X
\end{aligned}
$$

where $A^{*}=(I-A)^{-1}\left(A_{n}-A\right)$.

Account multiplier matrix $\left(M_{a}\right)$ can be expressed in the form of addition [53], which can be decomposed into the sum of four parts:

$$
M_{a}=1+\left(M_{a 1}-I\right)+\left(M_{a 2}-I\right) M_{a 1}+\left(M_{a 3}-I\right) M_{a 2} M_{a 1}
$$

where $\mathrm{T}=\left(M_{a 1}-I\right) ; \mathrm{O}=\left(M_{a 2}-I\right) M_{a 1} ; \mathrm{C}=\left(M_{a 3}-I\right) M_{a 2} M_{a 1} ; M_{a 1}=(I-A)^{-1} ; M_{a 2}=\left(I+A^{*}+A^{* 2}\right)$; $M_{\mathrm{a} 3}=\left(I-A^{* 3}\right)^{-1}$.

Specifically, I represents initial unit injection in renewable energy or coal energy sector; T represents the net contribution of transfer multiplier effect, reflecting the transfer effect of investment in renewable energy or coal energy sector on production accounts; $O$ represents the net contribution of open-loop effect or spillover effect, describing the relationships among three types of endogenous accounts; $\mathrm{C}$ represents the net contribution of closed-loop effect or feedback effect, implying the cyclic flow of large-scale energy investment between endogenous accounts. 


\subsection{Structural Path Analysis}

The results of SAM multiplier analysis can provide a quantitative reference, but the information obtained is very limited. Furthermore, the mechanism of exogenous injection is still a "black box", and the interaction process between various accounts in SAM is still unclear for decision makers. Fortunately, the structural path analysis is able to open the "black box". It reveals the path along which the exogenous injection is delivered to each end and the effect of exogenous injection in different transmission paths.

Generally, structural path analysis is described by a system of equations, where the size of each variable depends on one or more other variables. It is closely related to the model describing the social and economic reality. SPA method was developed by Lantner [54] who applied it to IO model then. Defourny and Thorbecke [50] first introduce SPA method to SAM model, they use structural path analysis to study the impact of specific production activities on other production activities, production factors and different households, and reveal the path and mechanism of the influence of exogenous variables on endogenous variables. The SPA method based on the SAM framework mainly reveals the mutual influence and influence path between accounts. Interaction between accounts can be divided into three categories: direct effect, total effect and global effect.

As shown in Figure 1, the structural path method regards each endogenous account in SAM as a knot, and the relationship between any two knots is expressed in arc $(i, j)$. The elements $a_{j i}$ in the average expenditure propensity matrix $A_{n}$ are defined as the magnitude of the influence transmitted from the knots $i$ (expenditure account) to the knots $j$ (revenue account), and are usually expressed as the intensity of the arc $(i, j)$.

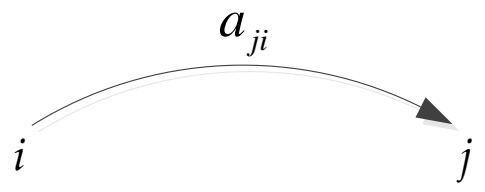

Figure 1. Topology of Inter-Account Linkages.

The continuous arcs $(i, k),(k, l), \cdots(m, j)$ formed by a series of knots $i, k, l, \cdots, m, j$ are generally called paths. The number of arcs contained in each path is called the length of the path. Generally, it is considered that a basic path does not pass through any knots repeatedly, and the path where the starting and ending knots coincide is usually called a loop. In Figure $2, i \rightarrow x \rightarrow y \rightarrow j$ is a basic path, and $x \rightarrow y \rightarrow z \rightarrow x$ is a loop.

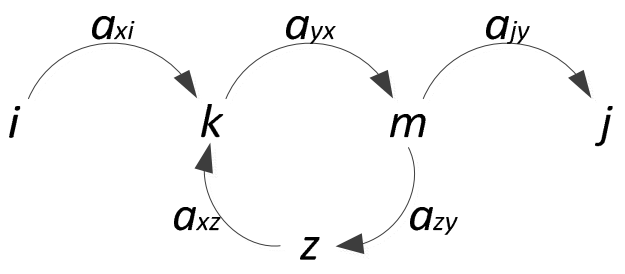

Figure 2. Basic Path.

The account $i$ in SAM is subjected to exogenous shocks, and it act on account $j$ through path $s$. The effect of this path is usually expressed as $(i \rightarrow j) s$. Generally, the effects from the beginning to the end can be quantitatively classified into three categories: direct effect, total effect and global effect.

(1) Direct effect

It refers to the direct impact of the starting knots $i$ on the ending knots $j$ along the basic path. It also denotes the impact of a unit change in the income of account $i$ on the income of account $j$, when all accounts except those represented by the knots on the basic path remain unchanged. 
The direct effect of account $i$ on account $j$ in SAM is the intensity of arcs $(i, j)$, that is the value $a_{j i}$ in the average expenditure propensity matrix $A_{n}$ :

$$
I_{(i \rightarrow j)}^{D}=a_{j i}
$$

Thus, the average expenditure propensity matrix $A_{n}$ is also called the direct impact matrix, where each element represents the intensity of an arc. The value of direct effect is equal to the product of the intensity of the arcs when a basic path with $i$ and $j$ as end knots passes through multiple knots:

$$
I_{(i \rightarrow j)}^{D}=a_{j y} \cdots a_{x i}
$$

(2) Total effect

In a given basic path $p=(i, \cdots, j)$ with starting knots $i$ and ending knots $j$, The total effect of the starting knots $i$ to ending knots $j$ along the path $P$ is the sum of the direct effect of this path and all the indirect effect of the loops of the knots on the basic path, that is,

$$
I^{D}{ }_{(i \rightarrow j) P}=I_{(i \rightarrow j) P}^{D} M_{P}
$$

where $I^{D}{ }_{(i \rightarrow j) P}$ refers to the direct effect of the starting knots $i$ to ending knots $j$ along the path $P$; $M_{P}$ refers to path multiplier, indicating the extent to which the direct effect in transmission process along the basic path is enlarged through the feedback loop. Generally, the value of $M_{P}$ is equal to the quotient of two determinants $\Delta_{p} / \Delta$, where $\Delta$ is the value of determinant $\left|I-A_{n}\right|$, and $\Delta_{p}$ is a determinant value of the subdeterminant obtained by deleting each knots of the basic path based on determinant $\left|I-A_{n}\right|$.

(3) Global effect

The global effect is a synthesis and abstraction of the effects of all paths between the starting and ending knots rather than describing the transmission effects of a particular path. The degree of global effect is represented by the elements in the account multiplier matrix $M_{a}$. Account multiplier matrices are also commonly referred to as global impact matrices. When the exogenous demand for account $i$ increases, the global effect on account $j$ is the value of elements in position $(i, j)$ in account multiplier matrix $M_{a}$, that is,

$$
I_{(i \rightarrow j)}^{G}=M_{a j i}
$$

To sum up, supposing there are $P$ basic paths between the starting knot $i$ and ending knot $j$, the relationship between the above three types of effects can then be expressed as:

$$
I_{(i \rightarrow j)}^{G}=M_{a j i}=\sum_{p=1}^{n} I_{(1 \rightarrow j) p}^{T}=\sum_{p=1}^{n} I_{(i \rightarrow j) p}^{D} M_{p}
$$

There are numerous basic paths in a complex social and economic system. It is helpful for policy makers to deeply understand the mechanism of exogenous injection by finding out the paths with greater global influence and analyzing their structures in detail. Meanwhile, it can also provide guidance for policy designers to identify the impact of policy measures on social and economic activities.

\subsection{Data}

The establishment of social accounting matrix (SAM table) is a basis for SAM multiplier analysis and SPA analysis. This paper builds a SAM table that includes 30 industrial sectors, residents, enterprises, government, investment and savings and foreign sector based on China's Input-Output Table of 2012 and Input-Output Continuation Table of 2015. In addition to these, the data used are also from the China Statistical Yearbook, China Financial Yearbook and China Energy Statistical Yearbook. The oil and gas 
sector is divided into oil sector and natural gas sector, and the power sector is divided into thermal power sector and renewable energy power sector in order to build a micro SAM table on the basis of macro background. More specifically, the power sector in the input-output table is divided into thermal power $78.82 \%$ and $73.1 \%$ in 2012 and 2015, respectively, according to the proportion of electricity production in China Electricity Statistical Yearbook in 2013 and 2016. Compared with the thermal power sector, the renewable energy sector does not need coal, oil and natural gas. The oil and gas industry in the input-output table is divided into oil 77.98\% and 75.97\% in 2012 and 2015, respectively, based on the energy consumption in China Energy Statistics Yearbook in 2013 and 2016.

\section{Results and Discussion}

\subsection{Energy Consumption Structure}

Currently, renewable energy industry is developing rapidly, with its share in energy consumption structure growing over time. As shown in Figure 3, the coal consumption accounted for more than 60\% during 2008-2017, which is still the most important energy source in China. Put differently, China's current energy consumption structure is still dominated by coal, and the coal industry plays a leading role in the national economy. Yet, the total consumption of hydropower, wind power and nuclear power was increasing over 2008-2017. Note that the share of them almost show a linear growth after 2011, indicating that the rapid development of renewable energy industry will inevitably impact the development of traditional coal industry. In addition, the proportion of renewable energy will be further expanded. At the Paris Climate Conference held in 2015, China proposed in the "National Independence Contribution" that non-fossil energy accounted for about $20 \%$ of primary energy consumption in 2030.

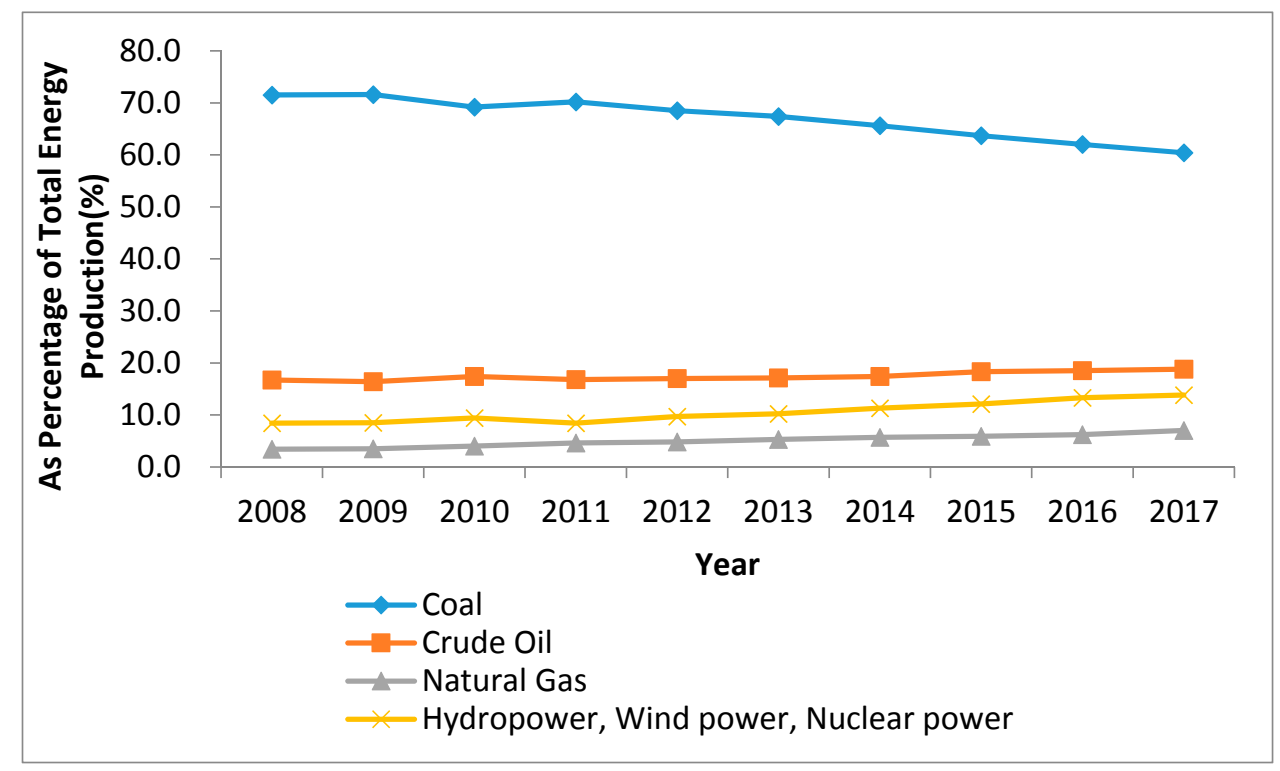

Figure 3. China's energy consumption structure map for 2008-2017 (Data source: China Statistical Yearbook (2009-2018)).

\subsection{The Effects on Overall Economy}

As shown in Figure 4, the SAM multiplier of the renewable energy sector was 5.531 in 2015. It indicates that one unit of investment increase of renewable energy can lead to 5.531 units increase in overall economy, which increased by $16.31 \%$ compared with 2012 . This shows that the effects of renewable energy on overall economy were increasing. The SAM multiplier of the coal sector was 5.187 in 2015, which increased by $22.65 \%$ compared with 2012, indicating an enhanced influence of coal energy on overall economy as well. Note that the SAM multiplier of the coal sector in these two years 
(2012 and 2015) was lower than that of the renewable energy sector. It shows the effects of traditional coal sector on the economy were weaker than those of the renewable energy sector. These results are not only in line with our expectations but also similar to other studies. For example, Tiwarii find coal consumption growth has a negative impact on GDP, while renewable energy consumption growth has a positive impact on the economy based on a data analysis of 16 European and Eurasian countries [55]. Ozturk and Bilgili onducted a survey across 51 African countries, finding that a $1 \%$ increase in biomass would increase GDP by $0.82 \%$ [56]. Chien and Hu believe that increasing the use of renewable energy can improve economic and technological efficiency, while increasing the input of traditional energy will reduce economic and technological efficiency [57].

Yet, the growth of SAM multiplier of coal sector is larger compared to the renewable energy sector, which is mainly due to the increase in transfer effect. In 2015, the transfer effect of the coal industry increased by $57.07 \%$ compared with 2012 . This means that the coal industry is closely related to other industrial sectors. The reason may be that the coal industry develops clean technology for coal utilization to promote industry upgrading under the influence of replacement pressure from renewable energy. For example, the application of water-saving technology in the coal industry chain has continuously promoted the development of the coal industry in the direction of deep processing [58].

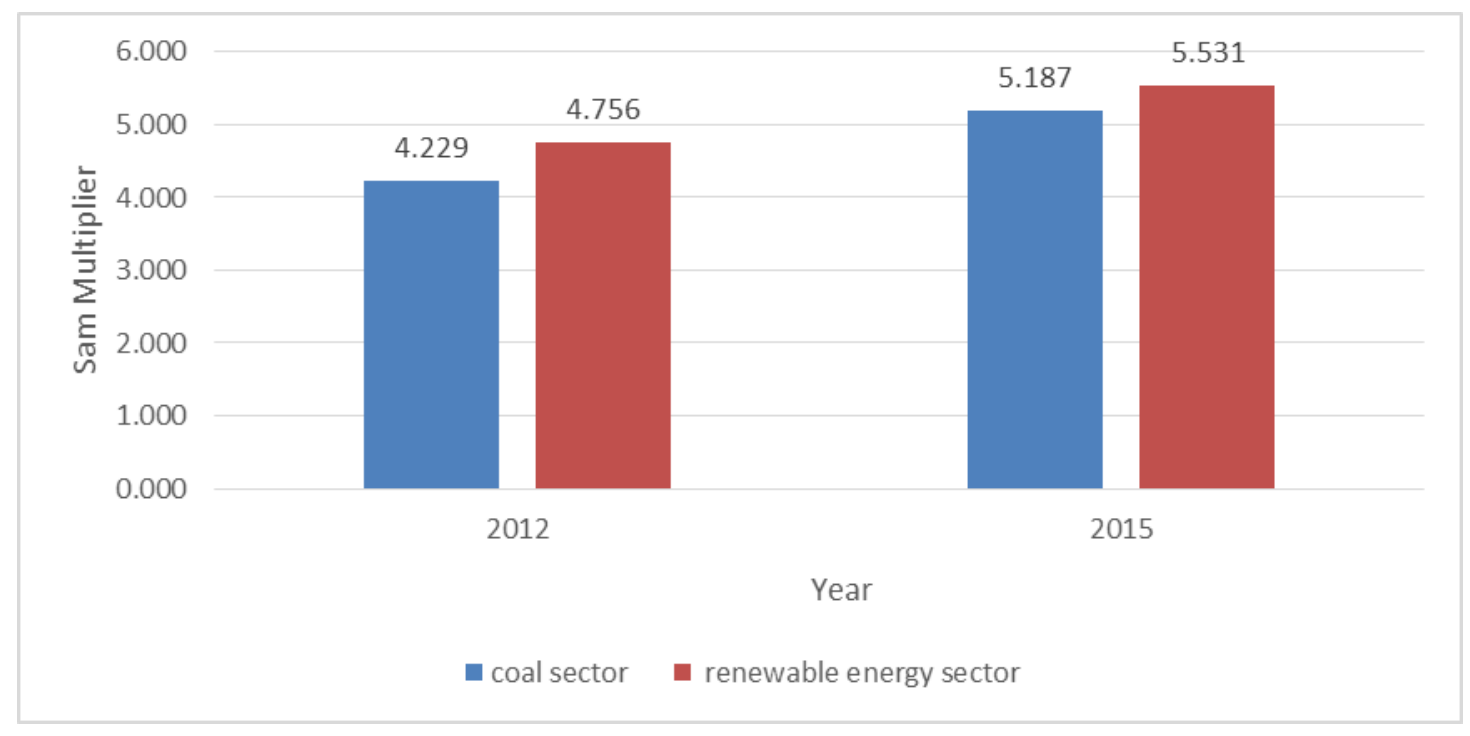

Figure 4. SAM multiplier of renewable energy sector and coal sector in 2012 and 2015.

The effects of the renewable energy sector on economy can be further decomposed into transfer effect, open-loop effect and closed-loop effect [52], which can reflect the impact of exogenous shocks on production activities, production factors and institutions (residents, enterprises) (Table 2). Transfer effect reflects the impact of exogenous shocks of sector accounts on production activity, production factor and institution blocks. Renewable energy belongs to the production account sector, and its transfer effect mainly lies in the increase of exogenous demand that leads to the increase of output in other sectors of the production system, reflecting the transfer of intermediate input between different industries. Coal industry belongs to the primary product processing sector with a relatively short industrial chain [17], thus the transfer effect that reflects the degree of industrial correlation is weak. In contrast, the industrial chain of renewable energy is longer and its transfer effect is stronger. Take wind power industry as an example, wind power production generally includes three stages: pre-planning and design, wind farm construction and wind farm operation. In the first stage, wind energy resources measurement and evaluation, wind farm engineering planning and micro-location are needed, which mainly refers to the production and service sectors such as technology research and development as well as information technology services. The second stage mainly includes building construction, purchase, installation and debugging of wind power equipment and instruments, which 
is closely related to the construction sector and electrical machinery manufacturing sector. Wind farm operation stage includes equipment spare parts supply, equipment maintenance, electronic equipment monitoring, referring to the instrument manufacturing sector, producer services and other sectors [20]. In addition, the above sectors involved in wind power generation need input from other sectors at different stages of their production, which in turn promotes the output of the whole production system through the correlation between sectors. The transfer effect of the renewable energy sector was 2.234 in 2015 (Table 2), indicating that one unit of investment increase of renewable energy can lead to 2.234 units increase in the output of production sectors. Open-loop effect measures the shock between any two different blocks (production activities, production factors and institutions). The open-loop multiplier effect of the renewable energy sector was 1.655 in 2015, showing that one unit of investment increase of renewable energy is accompanied by 1.655 units increase in the labor, capital, household income and enterprise income. Closed-loop effect reflects the multiplicative effect of exogenous shocks on endogenous accounts through economic cycle, that is from production activity to production factor and to institution (household and enterprise income), and then back to production activity. The closed-loop effect of the renewable energy sector was 1.643 in 2015, which indicates that one unit of investment increase of renewable energy can result in 1.643 units increase in the output of the production sectors. This capital flow circulates in the economic system: the increase of investment affects the demand for factors, which in turn affects the income and consumption of institutions, thus further feeding it back to the production sector. It can be seen that the closed-loop effect of the renewable energy sector accounts for the highest proportion (40.4\%) in the total impact indicating that the higher impact of the renewable energy sector on the economy is mainly due to its strong industrial relevance and high level of cross-sector relevance.

Table 2. SAM Multiplier Decomposition of Renewable Energy Sector and Coal Sector in 2012 and 2015.

\begin{tabular}{ccccccccc}
\hline \multirow{2}{*}{ Year } & Sector & $\begin{array}{c}\text { SAM } \\
\text { Multiplier }\end{array}$ & $\begin{array}{c}\text { Transfer } \\
\text { Effect }\end{array}$ & $\begin{array}{c}\text { Proportion } \\
\mathbf{( \% )}\end{array}$ & $\begin{array}{c}\text { Open-Loop } \\
\text { Effect }\end{array}$ & $\begin{array}{c}\text { Proportion } \\
\mathbf{( \% )}\end{array}$ & $\begin{array}{c}\text { Close-Loop } \\
\text { Effect }\end{array}$ & $\begin{array}{c}\text { Proportion } \\
(\%)\end{array}$ \\
\hline \multirow{2}{*}{2012} & $\begin{array}{c}\text { Coal sector } \\
\text { renewable } \\
\text { energy sector }\end{array}$ & 4.229 & 1.167 & 27.60 & 1.397 & 33.00 & 1.665 & 39.40 \\
& 4.756 & 1.861 & 39.10 & 1.507 & 31.70 & 1.388 & 29.20 \\
\hline \multirow{2}{*}{2015} & $\begin{array}{l}\text { Coal sector } \\
\text { renewable } \\
\text { energy sector }\end{array}$ & 5.187 & 1.833 & 35.30 & 1.455 & 28.10 & 1.898 & 36.60 \\
& 5.531 & 2.234 & 40.40 & 1.643 & 29.70 & 1.655 & 29.90 \\
\hline
\end{tabular}

As can be seen from Table 2, the transfer, open-loop and closed-loop effect of the traditional coal sector were 1.833, 1.455 and 1.898 in 2015, respectively, with the closed-loop effect being the highest proportion $(36.6 \%)$. It shows that the coal sector has a strong ability to drive the economy in a cyclic way. Note that the transfer effect of the coal sector was increasing compared with 2012. This may be because clean technology for coal utilization has become an important measure to improve energy efficiency and environmental quality, which has led to the growth of the coal industry chain, resulting in increased industrial relevance of the coal sector [59].

Compared to the coal sector, it is found that the transfer, open-loop and closed-loop effect of renewable energy sector on economic growth were $0.694,0.11$ and -0.277 higher in 2012 , and 0.401 , 0.188 and -0.243 higher in 2015, respectively. This indicates that the transfer and open-loop effect of renewable energy sector on economy is greater than that of coal sector. Moreover, the transfer effect plays the most important role, which means that the contribution of renewable energy to economic growth mainly lies in its stimulating effect on the output of relevant productive sectors. This may be because the industrial relevance of renewable energy is higher than that of coal industry that belongs to the primary product sector and shows a low demand for input from other industrial sectors [17]. Moreover, the renewable energy sector has a higher initial investment in the production process compared to the coal sector. Factor income is distributed to residents and enterprises, which enhances the driving role of elements and institutional accounts [32]. However, the growth rate of transfer effect in coal sector $(7.7 \%)$ is larger than that in renewable energy sector $(1.2 \%)$. This may be because the 
cleaner transformation and deep processing of coal resources have led to the extension of the coal industrial chain [39]. In addition, the closed-loop effect of the coal sector is higher than that of the renewable energy sector. It may be because the stimulating role of renewable energy industry is weaker in the early stage of development. That is, the initial cost of renewable energy development is high, which may have a negative impact on the economy during the initial stage [32,33].

\subsection{The effects on Economic Sectors}

\subsubsection{The Manufacturing Sector}

As shown in Table 3, the impacts of the renewable energy sector on the manufacturing industry in 2012 and 2015 are mainly reflected in the manufacturing of electrical machinery and equipment, communications and computer equipment, instrumetation, transportation equipment and general equipment. This result is in line with the finding of Dai who argues that large-scale development of renewable energy can have a significant stimulating effect on upstream industries such as machinery and electronic equipment manufacturing [1]. Compared to 2012, exogenous investment in renewable sector had the greatest increase in the impact on metal products machinery and equipment maintenance services $(61.4 \%)$ in 2015 , followed by transportation equipment manufacturing $(53.2 \%)$ and communication equipment computer and electronic equipment manufacturing (45.1\%).

Table 3. Overall impacts of the renewable energy sector and the coal sector on manufacturing and producer service sector in 2012 and 2015.

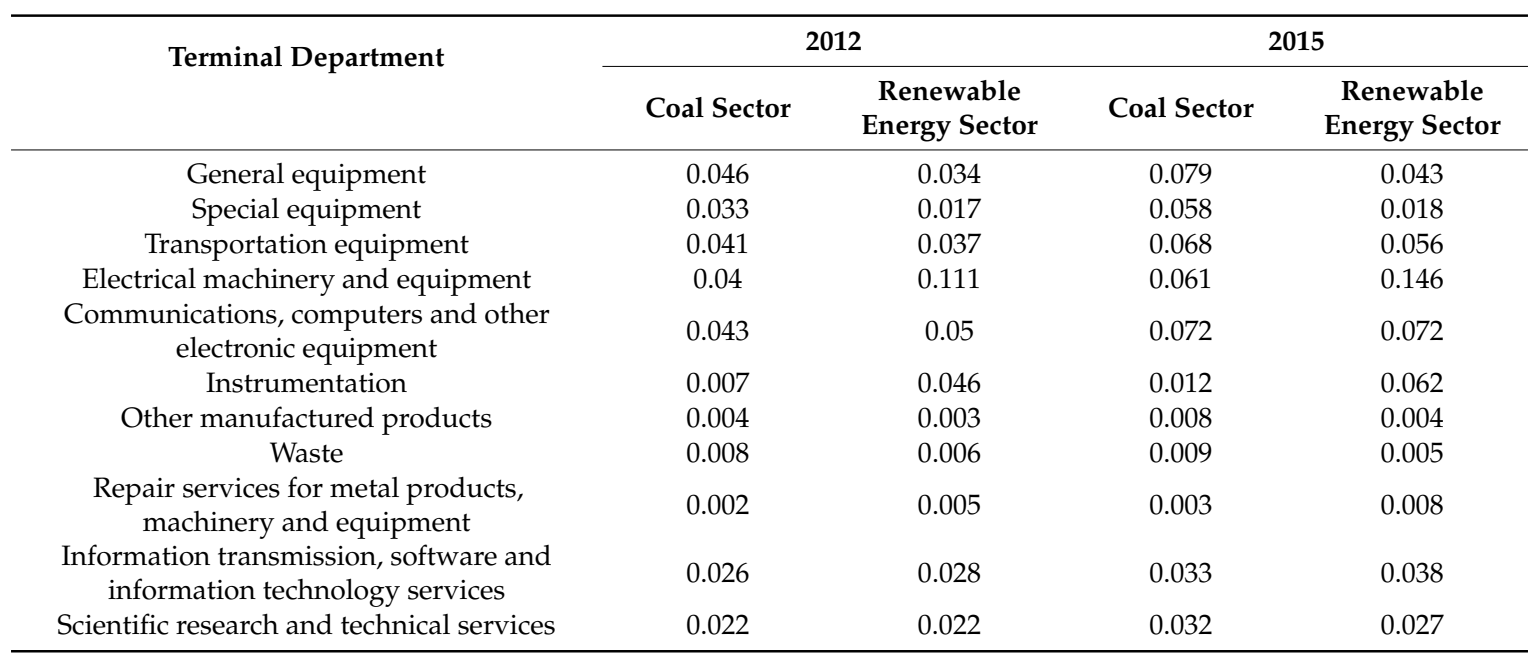

The impacts of coal sector on manufacturing industry in 2012 and 2015 are mainly reflected in the manufacturing of general equipment, communications and computer equipment, transportation equipment, electrical machinery and equipment and special equipment. Compared to 2012, exogenous investment in the coal energy sector had the greatest increase in the impact on other manufacturing industries in $2015(79 \%)$, followed by metal products machinery and equipment maintenance services (75\%) and specialized equipment manufacturing $(74 \%)$.

The total impacts of the renewable energy sector on the manufacturing sector were higher than that of the coal industry by 0.085 in 2012 and 0.044 , in 2015, respectively.

This indicates that the driving effect of renewable energy sector on the total output of manufacturing industry is higher than that of coal sector.

\subsubsection{The Producer Service Sector}

The value of the renewable energy sector on the information transmission, software and information technology service industries was 0.038 in 2015, indicating that one unit of investment increase of 
renewable energy can lead to 0.038 units increase in the output of these industries. However, the value of the coal sector on these industries was lower (0.033), implying that the role of renewable energy sector in driving high-tech industries is stronger than that of coal sector.

In 2015, the value of renewable energy sector on science research and technology service industry was 0.027 , which was lower than that of coal sector (0.032). It shows that per unit of investment in renewable energy sector has less impact on the promotion of scientific research and technological services industry compared to coal sector. This may be because the coal sector accounts for a large proportion of industrial added value and has a strong locking effect on industrial development. Even if cheaper and more efficient renewable energy technologies are available, traditional coal technologies will continue to exist and absorb investment in coal-related industries due to sunk costs [60]. As a result, investment in each unit of the coal sector may have led to more investment in engineering technology research experiments, geological exploration and engineering survey, thus increasing the output of scientific research and technical service industries.

Compared to the coal sector, the overall impact of the renewable energy sector on the production and service industries was higher in 2015, indicating that the driving effect of renewable energy sector on the total output of producer service sector is higher than that of coal sector.

\subsection{The Effects on Production Factors}

Multiplier decomposition can reveal the transfer effect of exogenous injection from coal and renewable energy sector within and between blocks. Structural path analysis can further determine the path network among production accounts, factor accounts and institutional accounts, and identify the key path of exogenous shock transmission. Because the number of paths increases exponentially with the increase of basic knots, the influence threshold [52] is used to show only the effect along up to two arcs in the basic path. It is known that labor and capital play an important role in determining the level of GDP. Econometric theory also holds that there is a causal relationship between GDP level and total capital and labor [61]. Therefore, we study the transmission path of capital and labor factors from two sectors to identify the key path of the impact of exogenous injection of renewable and coal energy on the economy.

The value of the global effect of the renewable energy sector on capital was 0.5590 , which was higher than that on labor (0.5314). This means that the capital gains brought by per unit of investment in the renewable energy sector are higher than the labor gains, indicating the capital-intensive characteristics of the renewable energy sector. The direct transmission effect of renewable energy sector on capital is the largest (30.5\%) among the paths listed. It shows that $30.5 \%$ of the impact of the renewable energy sector on capital gains can be explained by direct payments from the renewable energy sector, without the intervention of intermediate production sector. The impact of renewable energy on capital gains can also be transmitted through the intermediate sector, such as thermal power sector (renewable energy sector-thermal Power Sector-capital gains), other services sector (renewable energy sector-other services sector-capital gains), electrical machinery manufacturing sector (renewable energy sector-electrical machinery manufacturing sector-capital gains), transportation sector (renewable energy sector-transportation Sector-capital gains) (Table 4). This means that thermal power, other services, electrical machinery manufacturing and transportation manufacturing are all intermediate inputs of the renewable energy sector. The growth of renewable energy investment leads to the increase of investment in the intermediate input sector, which in turn leads to the growth of capital gains. The total impact of these four paths accounted for $15.07 \%, 8.59 \%, 0.99 \%$ and $0.68 \%$ of the total impact of renewable energy investment on capital gains, respectively. 
Table 4. Impact Path of Renewable Energy Sector and Coal Sector on Production Factor in 2015.

\begin{tabular}{|c|c|c|c|c|c|c|}
\hline Sector & Terminal Account & Global Effect & Basic Path & Total Effect & Proportion $(\%)$ & Cumulative Impact (\%) \\
\hline \multirow{10}{*}{ Coal sector } & \multirow{5}{*}{ Labor } & \multirow{5}{*}{0.6613} & Coal Sector-Labor & 0.3004 & 45.43 & 45.43 \\
\hline & & & Coal Sector-Other Services-Labor & 0.1110 & 16.79 & 62.22 \\
\hline & & & Coal Sector-Transportation-Labor & 0.0150 & 2.26 & 64.48 \\
\hline & & & Coal Sector-Metal Smelting-Labor & 0.0108 & 1.63 & 66.12 \\
\hline & & & Coal Sector-Wood Processing-Labor & 0.0061 & 0.92 & 67.04 \\
\hline & \multirow{5}{*}{ Capital } & \multirow{5}{*}{0.4007} & Coal Sector-Capital & 0.0761 & 19.00 & 19.00 \\
\hline & & & Coal Sector-Other Services-Capital & 0.0736 & 18.37 & 37.37 \\
\hline & & & Coal Sector-Thermal Power-Capital & 0.0091 & 2.27 & 39.64 \\
\hline & & & Coal Sector-Metal Smelting-Capital & 0.0090 & 2.24 & 41.88 \\
\hline & & & Coal Sector-Transportation-Capital & 0.0076 & 1.91 & 43.78 \\
\hline \multirow{10}{*}{$\begin{array}{l}\text { Renewable energy } \\
\text { sector }\end{array}$} & \multirow{5}{*}{ Labor } & \multirow{5}{*}{0.5314} & Renewable Energy Sector-Labor & 0.1171 & 22.04 & 22.04 \\
\hline & & & $\begin{array}{c}\text { Renewable Energy Sector-Other } \\
\text { Services-Labor }\end{array}$ & 0.0726 & 13.66 & 35.70 \\
\hline & & & $\begin{array}{c}\text { Renewable Energy Sector-Thermal } \\
\text { Power Sector-Labor }\end{array}$ & 0.0483 & 9.09 & 44.79 \\
\hline & & & $\begin{array}{l}\text { Renewable Energy Sector-Electrical } \\
\text { Machinery-Labor }\end{array}$ & 0.0080 & 1.50 & 46.29 \\
\hline & & & $\begin{array}{l}\text { Renewable Energy } \\
\text { Sector-Transportation-Labor }\end{array}$ & 0.0074 & 1.40 & 47.69 \\
\hline & \multirow{5}{*}{ Capital } & \multirow{5}{*}{0.5590} & Renewable Energy Sector-Capital & 0.1706 & 30.52 & 30.52 \\
\hline & & & $\begin{array}{l}\text { Renewable Energy Sector-Thermal } \\
\text { Power-Capital }\end{array}$ & 0.0843 & 15.07 & 45.60 \\
\hline & & & $\begin{array}{c}\text { Renewable Energy Sector-Other } \\
\text { Services-Capital }\end{array}$ & 0.0480 & 8.59 & 54.19 \\
\hline & & & $\begin{array}{c}\text { Renewable Energy Sector-Electrical } \\
\text { Machinery-Capital }\end{array}$ & 0.0055 & 0.99 & 55.18 \\
\hline & & & $\begin{array}{l}\text { Renewable Energy } \\
\text { Sector-Transportation-Capital }\end{array}$ & 0.0038 & 0.68 & 55.85 \\
\hline
\end{tabular}


The impacts of renewable energy on capital can be divided into direct and indirect ones. One refers to the large-scale deployment of renewable energy directly leads to increased capital investment in the renewable energy sector. The other mainly lies in the huge demand for investment products. For example, the demand for wind turbines and silicon panels for photovoltaic power and wind power generation has stimulated the output of related upstream industries of renewable energy, which influences capital gains through the intermediate industry sector. Similarly, in the path of renewable energy to labor income, the direct path of "renewable energy sector to labor force" accounted for the largest proportion of $22.04 \%$. Then it is conducted by other intermediate input departments such as service industry, thermal power, electrical machinery, transportation and manufacturing, etc. The total impact of the path is $13.66 \%, 9.09 \%, 1.50 \%$ and $1.40 \%$ of the global impact, respectively.

Different from the renewable energy sector, the value of global impact of coal sector on capital is 0.4007 , lower than that on labor factor (0.6613). It shows the labor-intensive characteristics of coal mining industry at present. Similar to renewable energy sector, coal sector has the greatest direct transmission effect on capital (19\%). However, different from renewable energy, other paths mainly affect capital through other services, thermal power, metal smelting and transportation industries. The proportion of transmission paths was $18.37 \%, 2.27 \%, 2.24 \%$ and $1.91 \%$, respectively.

The total impact of renewable energy on capital is higher than that of coal industry. It shows that investment in renewable energy sector can obtain higher capital gains compared to the coal sector, but its labor gains are lower. In the path of coal sector on labor, the proportion of direct effect "coal mining industry to labor force" reached $45.4 \%$. It shows that coal industry has a strong direct effect on labor income, while investment in renewable energy sector mainly has an indirect effect on labor income, indicating a strong industrial relevance of renewable energy sector. The reasons for the weak impact of the renewable energy sector on labor income mainly lie in two aspects. For one thing, renewable energy is in the initial stage of development, with less demand for labor force; For another, the development of renewable energy has crowded out investment in traditional energy sector [62], resulting in the weakening of traditional resource-intensive industries such as mining, cement, steel, construction and other industries, thereby leading to the unemployment of labor force. The value of the renewable energy sector on labor was 0.5314 in 2015, higher than 0.4943 in 2012. This is because infrastructure construction, manufacturing and maintenance of power generation facilities can create more employment opportunities. For example, Dai predict that large-scale renewable energy development would create 4.12 million jobs by 2050 by stimulating upstream related industries [1]. In addition, as a technology-intensive industry, renewable energy sector needs more high-skilled labor force and increases labor income.

\section{Conclusions}

This paper uses a SAM multiplier model to study the effects of renewable energy development on China's overall economic. The SPA method is also adopted to study the transmission mechanism of renewable energy on China's economy from the perspective of sector industrial chain. In addition, the mechanisms of renewable and coal energy on economic growth are compared. The main conclusions are as follows.

Firstly, renewable energy has a stronger promoting effect to the national economy compared to coal energy. This is mainly due to its transfer effect, that is, the development of renewable energy plays a leading role in other industries. In addition, there is a greater demand for investment goods with the scale expansion of renewable energy, resulting in the improvement of cross-sector linkages in the renewable energy sector. For example, the increasing demand for mechanical equipment such as wind turbines and silicon panels for photovoltaic and wind power generation has stimulated the output of relevant industries of renewable energy.

Secondly, renewable energy plays a more important role in promoting the upgrading of industrial structure compared to coal energy. The impact of renewable energy on manufacturing industry mainly lies in the electrical machinery and equipment, communications and computer equipment 
manufacturing, and instrumentation. The impact of coal energy on manufacturing industry mainly lies in the general equipment manufacturing, communications and computer equipment manufacturing, transportation equipment.

Thirdly, the capital income from per unit of investment in renewable energy sector is higher than that of labor income, reflecting the capital-intensive characteristics of the early development stage of renewable energy sector. The promoting effect of renewable energy on capital and labor income mainly comes from its indirect path, where renewable energy mainly affects production factors through electrical machinery manufacturing and transportation, warehousing and service industries.

The competition between renewable energy and traditional fossil energy is widespread across many countries. Our findings show that renewable energy sector plays a stronger role in driving the economy than coal sector. Some important policy implications may arise. First, the development of renewable energy-related industries should be encouraged. More specifically, the Chinese government should encourage public and private capital to invest in renewable energy-related industries with the scale expansion of renewable energy and the increasing consumption of investment products in related industries. Energy planners and relevant energy agencies need work together to increase investment in renewable energy to promote the low-carbon growth of economy. Second, the impact of renewable energy development on labor income should be considered when formulating relevant measures. The development of renewable energy will inevitably squeeze the output of the traditional fossil energy sector, resulting in unemployment. Thus, measures such as the re-employment of the unemployed labor force in the traditional fossil energy sector, cultivating high-skilled labor force should be taken into account. Therefore, the increase of labor income can be realized through the capacity improvement of labor force. Last, policy-maker should introduce incentives to encourage renewable energy enterprises to increase $R \& D$ investment and prevent low value-added development of renewable energy industry. However, some limitations of the current study are apparent. Although the data in this paper are mainly derived from the latest input-output table of China in 2015, renewable energy analysis based on updated data can better reflect recent changes. Moreover, the model itself ignores the impact of industry scale returns, with the hypothesis of linear production function. That is, the relationship between input and output is strictly proportional with no substitution between input factors. Last, the data of renewable energy industry in SAM table compiled in this paper comes from the separation of power sector data, because the input-output table lacks the industry data of renewable energy. Taking regional input and output into account, future research can establish China's multi-regional SAM table and to further study the economic effects of renewable energy.

Author Contributions: Methodology, J.L. (Jia Liu); data curation, J.L. (Jia Liu); writing—original draft preparation, J.L. (Jia Liu); writing-review and editing, J.L. (Jizu Li), X.Y.; project administration, J.L. (Jizu Li); funding acquisition, J.L. (Jizu Li).

Funding: This research was funded by the National Natural Science Foundation of China [grant number 41401655], the 2018 Shanxi Provincial Higher Education Humanities and Social Sciences Key Research Base Project [Project No: 2018 Shanxi University Base Project (Jin Education Section [2018] No. 33) and the Shanxi Graduate Education Innovation Program [grant number 2018BY043].

Conflicts of Interest: The authors declare no conflict of interest.

\section{References}

1. Dai, H.; Xie, X.; Xie, Y.; Liu, J.; Masui, T. Green growth: The economic impacts of large-scale renewable energy development in China. Appl. Energy 2016, 162, 435-449. [CrossRef]

2. Inglesi-Lotz, R. The impact of renewable energy consumption to economic growth: A panel data application. Energy Econ. 2016, 53, 58-63. [CrossRef]

3. Salim, R.A.; Hassan, K.; Shafiei, S. Renewable and non-renewable energy consumption and economic activities: Further evidence from OECD countries. Energy Econ. 2014, 44, 350-360. [CrossRef]

4. Apergis, N.; Payne, J.E. Renewable and non-renewable energy consumption-growth nexus: Evidence from a panel error correction model. Energy Econ. 2012, 34, 733-738. [CrossRef] 
5. Sastresa, E.L.; Usón, A.A.; Bribián, I.Z.; Scarpellini, S. Local impact of renewables on employment: Assessment methodology and case study. Renew. Sustain. Energy Rev. 2010, 14, 679-690. [CrossRef]

6. Moreno, B.; Lopez, A.J. The effect of renewable energy on employment. The case of Asturias (Spain). Renew. Sustain. Energy Rev. 2008, 12, 732-751. [CrossRef]

7. Hirschl, B.; Aretz, A.; Prahl, A.; Böther, T.; Heinbach, K.; Pick, D.; Funcke, S. Kommunale Wertschöpfung durch Erneuerbare Energien; IÖW: Berlin, Germany, 2010; pp. 38-51.

8. Jenniches, S. Assessing the regional economic impacts of renewable energy sources-A literature review. Renew. Sustain. Energy Rev. 2018, 93, 35-51. [CrossRef]

9. Apergis, N.; Salim, R. Renewable energy consumption and unemployment: Evidence from a sample of 80 countries and nonlinear estimates. Appl. Econ. 2015, 47, 1-20. [CrossRef]

10. Al-Mulali, U.; Fereidouni, H.G.; Lee, J.Y.; Che, N.B.C.S. Examining the bi-directional long run relationship between renewable energy consumption and GDP growth. Renew. Sustain. Energy Rev. 2013, 22, $209-222$. [CrossRef]

11. Menegaki, A.N. Growth and renewable energy in Europe: A random effect model with evidence for neutrality hypothesis. Energy Econ. 2011, 33, 257-263. [CrossRef]

12. Payne, J.E. On the dynamics of energy consumption and output in the US. Appl. Energy 2009, 86, 575-577. [CrossRef]

13. Markandya, A.; Arto, I.; González-Eguino, M.; Román, M.V. Towards a green energy economy? Tracking the employment effects of low-carbon technologies in the European Union. Appl. Energy 2016, 179, 1342-1350. [CrossRef]

14. Alikaj, M.; Alexopoulos, Y. Analysis of the Economy of Region of Western Greece. An Application of the Social Accounting Matrix (SAM). Procedia Econ. Financ. 2014, 14, 3-12. [CrossRef]

15. Akkemik, K.A. Assessing the importance of international tourism for the Turkish economy: A social accounting matrix analysis. Tour. Manag. 2012, 33, 790-801. [CrossRef]

16. Yao, X.; Kou, D.; Shao, S.; Li, X.; Wang, W.; Zhang, C. Can urbanization process and carbon emission abatement be harmonious? New evidence from China. Environ. Impact Assess. Rev. 2018, 71, 70-83. [CrossRef]

17. Shuai, S.; Zhongying, Q. Energy exploitation and economic growth in Western China: An emprical analysis based on the resource curse hypothesis. Front. Econ. China 2009, 4, 125-152.

18. Ruamsuke, K.; Dhakal, S.; Marpaung, C.O.P. Energy and economic impacts of the global climate change policy on Southeast Asian countries: A general equilibrium analysis. Energy 2015, 81, 446-461. [CrossRef]

19. Yildirim, E.; Saraç, Ş.; Aslan, A. Energy consumption and economic growth in the USA: Evidence from renewable energy. Renew. Sustain. Energy Rev. 2012, 16, 6770-6774. [CrossRef]

20. Slattery, M.C.; Lantz, E.; Johnson, B.L. State and local economic impacts from wind energy projects: Texas case study. Energy Policy 2011, 39, 7930-7940. [CrossRef]

21. Madlener, R.; Koller, M. Economic and $\mathrm{CO}_{2}$ mitigation impacts of promoting biomass heating systems: An input-output study for Vorarlberg, Austria. Energy Policy 2007, 35, 6021-6035. [CrossRef]

22. Varun; Prakash, R.; Bhat, I.K. Energy, economics and environmental impacts of renewable energy systems. Renew. Sustain. Energy Rev. 2009, 13, 2716-2721. [CrossRef]

23. Sari, R.; Ewing, B.T.; Soytas, U. The relationship between disaggregate energy consumption and industrial production in the United States: An ARDL approach. Energy Econ. 2008, 30, 2302-2313. [CrossRef]

24. Lehr, U.; Lutz, C.; Edler, D. Green jobs? Economic impacts of renewable energy in Germany. Energy Policy 2012, 47, 358-364. [CrossRef]

25. Apergis, N.; Payne, J.E. Renewable and non-renewable electricity consumption-growth nexus: Evidence from emerging market economies. Appl. Energy 2011, 88, 5226-5230. [CrossRef]

26. Blazejczak, J.; Braun, F.G.; Edler, D.; Schill, W.-P. Economic effects of renewable energy expansion: A model-based analysis for Germany. Renew. Sustain. Energy Rev. 2014, 40, 1070-1080. [CrossRef]

27. Sadorsky, P. Renewable energy consumption and income in emerging economies. Energy Policy 2009, 37, 4021-4028. [CrossRef]

28. Apergis, N.; Payne, J.E. Renewable energy consumption and economic growth: Evidence from a panel of OECD countries. Energy Policy 2010, 38, 656-660. [CrossRef]

29. Apergis, N.; Payne, J.E. Renewable energy consumption and growth in Eurasia. Energy Econ. 2010, 32, 1392-1397. [CrossRef] 
30. Apergis, N.; Payne, J.E. The renewable energy consumption-growth nexus in Central America. Appl. Energy 2011, 88, 343-347. [CrossRef]

31. Salim, R.A.; Rafiq, S. Why do some emerging economies proactively accelerate the adoption of renewable energy? Energy Econ. 2012, 34, 1051-1057. [CrossRef]

32. Frondel, M.; Ritter, N.; Schmidt, C.M.; Vance, C. Economic impacts from the promotion of renewable energy technologies: The German experience. Energy Policy 2010, 38, 4048-4056. [CrossRef]

33. Böhringer, C.; Keller, A.; van der Werf, E. Are green hopes too rosy? Employment and welfare impacts of renewable energy promotion. Energy Econ. 2013, 36, 277-285. [CrossRef]

34. Ocal, O.; Aslan, A. Renewable energy consumption-economic growth nexus in Turkey. Renew. Sustain. Energy Rev. 2013, 28, 494-499. [CrossRef]

35. Ozturk, I. A literature survey on energy-growth nexus. Energy Policy 2010, 38, 340-349. [CrossRef]

36. Chen, S.-T.; Kuo, H.-I.; Chen, C.-C. The relationship between GDP and electricity consumption in 10 Asian countries. Energy Policy 2007, 35, 2611-2621. [CrossRef]

37. Hannum, C.; Cutler, H.; Iverson, T.; Keyser, D. Estimating the implied cost of carbon in future scenarios using a CGE model: The Case of Colorado. Energy Policy 2017, 102, 500-511. [CrossRef]

38. Bulavskaya, T.; Reynès, F. Job creation and economic impact of renewable energy in the Netherlands. Renew. Energy 2018, 119, 528-538. [CrossRef]

39. Hondo, H.; Moriizumi, Y. Employment creation potential of renewable power generation technologies: A life cycle approach. Renew. Sustain. Energy Rev. 2017, 79, 128-136. [CrossRef]

40. Lantz, E. Economic Development Benefits from Wind Power in Nebraska: A Report for the Nebraska Energy Office; Technical Report NREL/TP-500-44344; National Renewable Energy Laboratory: Colorado, CO, USA, June 2009.

41. Allan, G. Regional Employment Impacts of Marine Energy in the Scottish Economy: A General Equilibrium Approach. Reg. Stud. 2015, 49, 337-355.

42. Sánchez-Chóliz, J.; Duarte, R.; Mainar, A. Environmental impact of household activity in Spain. Ecol. Econ. 2007, 62, 308-318. [CrossRef]

43. Fanning, T.; Jones, C.; Munday, M. The regional employment returns from wave and tidal energy: A Welsh analysis. Energy 2014, 76, 958-966. [CrossRef]

44. Li, Y.; Su, B.; Dasgupta, S. Structural path analysis of India's carbon emissions using input-output and social accounting matrix frameworks. Energy Econ. 2018, 76, 457-469. [CrossRef]

45. Miller, R.E.; Blair, P.D. Input-Output Analysis: Foundations and Extensions; Cambridge University Press: Cambridge, UK, 2009; pp. 499-541.

46. Böhringer, C.; Löschel, A. Computable general equilibrium models for sustainability impact assessment: Status quo and prospects. Ecol. Econ. 2007, 60, 49-64. [CrossRef]

47. Cansino, J.M.; Cardenete, M.A.; Gonzalez, J.M.; del P. Pablo-Romero, M. Economic impacts of solar thermal electricity technology deployment on Andalusian productive activities: A CGE approach. Ann. Reg. Sci. 2013, 50, 25-47. [CrossRef]

48. Tugcu, C.T.; Ozturk, I.; Aslan, A. Renewable and non-renewable energy consumption and economic growth relationship revisited: Evidence from G7 countries. Energy Econ. 2012, 34, 1942-1950. [CrossRef]

49. Pao, H.-T.; Fu, H.-C. Renewable energy, non-renewable energy and economic growth in Brazil. Renew. Sustain. Energy Rev. 2013, 25, 381-392. [CrossRef]

50. Defourny, J.; Thorbecke, E. Structural Path Analysis and Multiplier Decomposition within a Social Accounting Matrix Framework. Econ. J. 1984, 94, 111. [CrossRef]

51. Round, J. Social accounting matrices and SAM-based multiplier analysis. In The Impact of Economic Policies on Poverty and Income Distribution: Evaluation Techniques and Tools; The World Bank: Washington, DC, USA, 2003; Volume 14, pp. 261-276.

52. Pyatt, G.; Round, J.I. Accounting and fixed price multipliers in a social accounting matrix framework. Econ. J. 1979, 89, 850-873. [CrossRef]

53. Pyatt, G.; Round, J.I. Social Accounting Matrices: A Basis for Planning; The World Bank: Washington, DC, USA, 1985; pp. 145-185.

54. Lantner, R. Recherche sur l'interprétation du déterminant d'une matrice input-output. Revue d'économie politique 1972, 82, 435-442. 
55. Tiwari, A.K. Comparative performance of renewable and nonrenewable energy source on economic growth and $\mathrm{CO}_{2}$ emissions of Europe and Eurasian countries: A PVAR approach. Econ. Bull. 2011, 31, 2356-2372.

56. Ozturk, I.; Bilgili, F. Economic growth and biomass consumption nexus: Dynamic panel analysis for Sub-Sahara African countries. Appl. Energy 2015, 137, 110-116. [CrossRef]

57. Chien, T.; Hu, J.-L. Renewable energy and macroeconomic efficiency of OECD and non-OECD economies. Energy Policy 2007, 35, 3606-3615. [CrossRef]

58. Pan, L.; Liu, P.; Ma, L.; Li, Z. A supply chain based assessment of water issues in the coal industry in China. Energy Policy 2012, 48, 93-102. [CrossRef]

59. Glomsrød, S.; Wei, T. Coal cleaning: A viable strategy for reduced carbon emissions and improved environment in China? Energy Policy 2005, 33, 525-542. [CrossRef]

60. Loisel, R. Environmental climate instruments in Romania: A comparative approach using dynamic CGE modelling. Energy Policy 2009, 37, 2190-2204. [CrossRef]

61. Kahia, M.; Ben Aïssa, M.S.; Charfeddine, L. Impact of renewable and non-renewable energy consumption on economic growth: New evidence from the MENA Net Oil Exporting Countries (NOECs). Energy 2016, 116, 102-115. [CrossRef]

62. Zapped: The High Cost of Ontario's Renewable Electricity Subsidies. Available online: https://ideas.repec. org/p/cdh/ebrief/117.html (accessed on 31 May 2011).

(C) 2019 by the authors. Licensee MDPI, Basel, Switzerland. This article is an open access article distributed under the terms and conditions of the Creative Commons Attribution (CC BY) license (http://creativecommons.org/licenses/by/4.0/). 